\title{
Perishable Food Supply Chain, Supply of Chain Management on Risk Mitigation with Enterprise Risk Management as an Intervening Variable
}

\author{
Yasananda Khusnul Ramadiyanto \\ Trisakti University, Indonesia \\ Yvonne Augustine \\ Trisakti University, Indonesia
}

\begin{abstract}
This study examines the effect of perishable food supply chain and supply chain management on risk mitigation with enterprise risk management as an intervening variable. The design of this study is a form of survey research, the number of samples in this study were 52 respondents intended for employees in service companies in Indonesia. Keywords: Perishable Food Supply Chain, Supply of Chain Management, Risk Mitigation, Enterprise Risk Management.
\end{abstract}

DOI: $10.7176 / \mathrm{EJBM} / 11-12-22$

Publication date: April $30^{\text {th }} 2019$

\section{Background}

Basically, perishable food supply chain and supply chain management are the main focus for retail company management and external parties as a reference and basis in choosing products to consume by consumers. Risk Mitigation must be done immediately to minimize the risks that will occur in a company. Because if a company carries out risk mitigation properly. So the company will avoid the risks that occur in a company.

Enterprise Risk Management is creating a system or mechanism within the organization so that risks that can harm the organization can be anticipated and managed for the purpose of increasing the value of the company. Supply chain management (supply chain management) is the integration of the procurement of materials and services, conversion into semi-finished goods and end products, and delivery to customers (Heizer and Render, 2008).

Perishable Food Supply Chain is a food supply chain that exists in a company. The supply chain plays an important role in the food supply in the company to be able to work in accordance with the applicable Operational Standards. Perishable Food Supply Chain is very helpful for the management in determining the amount of food that is easily damaged. And find the right solution so that the occurrence of damaged food does not exist.

This research is different from previous research. Where in this study added the perishable food supply chain variable as an independent variable, whereas in the previous study there was no perishable food supply chain variable. And Enterprise Risk Management Variables as a variable intervening.

The contribution in my research is that there is a curiosity about how to minimize the risk of perishable food in a supermarket and find the right solution to avoid such conditions

\section{Literature Review}

Risk is closely related to uncertainty, which occurs because there is insufficient or unavailability of information about what will happen. Something that is uncertain (uncertain) can have a beneficial or detrimental effect. According to Wideman, uncertainties that give rise to favorable possibilities are known as opportunities (Opportunity, while uncertainties that cause adverse effects are known as risk).

\subsection{Perishable Food Supply Chain}

Perishable Food Supply Chain is a Supply Chain Food that is easily damaged and does not last long. Like eggs, milk and meat. Supply Chain for Fresh / Fresh Food Products (such as fresh vegetables, flowers, fruits). In general, the supply chain includes: farmers, collectors, wholesalers, importers and exporters, retailers and specialty stores. Basically, all stages of the supply chain have special characteristics, products are grown or produced from the countryside. The main processes are handling, storing, packaging, transporting and especially trading these products.

\subsection{Supply Chain Management}

Supply Chain Management (supply chain management) is the integration of procurement activities of materials and services, conversion into semi-finished goods and end products, and delivery to customers (Heizer and Render, 2008). Supply is the supply or stock of goods needed and can be obtained. So the supply chain or supply chain is 
an interconnected circle in order to get the items needed from the supplier / supplier. Of course there are many factors in the supply / supply chain circle.

Broadly speaking, SCM is a process for integrating, coordinating and controlling the movement of raw materials into finished products and sending them to consumers. Movement of information is also included in this process. All efforts are usually made so that the process can be carried out effectively and efficiently to maximize the value that can be obtained by consumers and to achieve a sustainable profit.

\subsection{Enterprise Risk Management}

Enterprise Risk Management can be specific risks (eg credit, operations, and markets), capital management, and interpret Enterprise risk management (ERM) is defined as risk competency within a company or organization. ERM is the organization's ability to understand and control the level of risk taken in managing business strategies, coupled with accountability for the risks taken. The main benefit of ERM is to add perspective and focus on risk management in all lines of the company.

The basic concept of corporate risk management has been applied in several industries for more than a decade. Changes in environmental regulations, economic turmoil, and increased complexity of products, tools, and also risks include helping to launch corporate risk management practices into the financial services area. The banking industry is faced with a variety of risks. The ERM framework is designed to support the depth and breadth of ERM activities by providing a structured approach to identifying, measuring, controlling, and reporting significant risks faced by an organization. Liquidity management provides essential foundations into the ERM framework.

\subsection{Risk Mitigation}

Risk mitigation can be interpreted as according, saying that the definition of mitigation can be defined. Definition of mitigation is a series of efforts to reduce disaster risk, both through physical development and awareness and capacity building in the face of disaster threats.

To carry out our risk management it is necessary to go through several processes, there are eight frameworks related to Risk Management, namely:
A. Internal environment
B. Objective setting
C. Event identification
D. Risk assessment
E. Risk response
F. Control activities
G. Information and communication (information and communication)
H. Monitoring

\section{Conceptual Framework}

The conceptual framework explains the relationship between the independent variables which consists of 2 (two) variables, namely Perishable Food Supply Chain and Supply Chain Management to the dependent variable namely Risk Mitigation and also there are intervening variables namely Enterprise Risk Management.

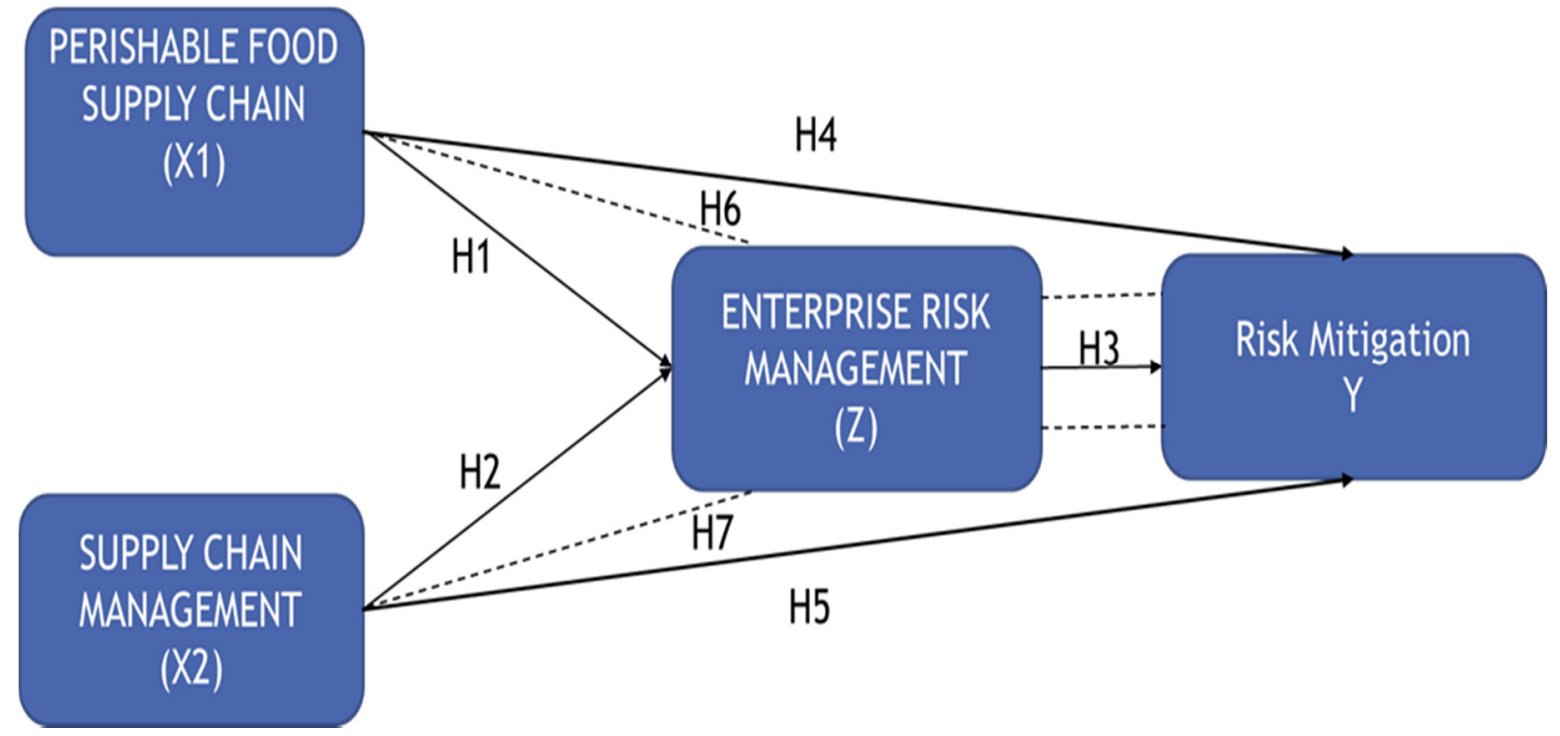




\section{Methodology Study}

\subsection{Sampel and Data}

The characteristics of the research respondents were profiles of 52 respondents who participated in filling out the research questionnaire. Profile of respondents explained about gender, age, length of work, education level, and occupation.

In this study using a sample of retail companies, companies included in the consumer goods industry sector. The object of the research used in this study is the consumer goods industry sector companies and those listed on the Indonesia Stock Exchange.

\subsection{Measurement}

Validity test is a test of question items in the questionnaire. This test was conducted to test whether the right instrument was used in this study. Question items are declared valid if they have strong support for the total score. The testing criteria are carried out using factor analysis testing. Decision making is done using criteria:

- $\mathrm{r}$ count $>0.3=$ Valid

- $\mathrm{r}$ count $<0.3=$ Invalid

Table 4.1

\section{MEASUREMENT}

\begin{tabular}{|c|c|c|c|}
\hline No & Variable & Definition & Instrument \\
\hline 1 & $\begin{array}{c}\text { Perishable } \\
\text { Supply Chain }\end{array}$ & $\begin{array}{l}\text { Supply Chain Food that is } \\
\text { easily damaged and does not } \\
\text { last long. Like eggs, milk and } \\
\text { meat. Supply Chain for Fresh / } \\
\text { Fresh Food Products (such as } \\
\text { fresh vegetables, flowers, } \\
\text { fruits). }\end{array}$ & $\begin{array}{l}\text { 1. Your company applies Identification of food } \\
\text { supply chain risk } \\
\text { 2. Company uses the identification strategy of } \\
\text { food supply chain } \\
\text { 3. Identification of food supply chain risk is } \\
\text { needed for company success } \\
\text { 4. Prevention of food supply chains is very } \\
\text { needed } \\
\text { 5. Companies do evaluation of food supply chains } \\
\text { in companies }\end{array}$ \\
\hline 2 & $\begin{array}{l}\text { Supply Chain } \\
\text { Management }\end{array}$ & $\begin{array}{l}\text { the integration of procurement } \\
\text { activities of materials and } \\
\text { services, conversion into semi- } \\
\text { finished goods and end } \\
\text { products, and delivery to } \\
\text { customers }\end{array}$ & $\begin{array}{l}\text { 1. Your company offers quality as the main } \\
\text { criteria in suppliers } \\
\text { 2. Your company is delivery following including } \\
\text { suppliers in giving quality of food in the } \\
\text { company } \\
\text { 3. Your company looks know the market desire } \\
\text { 4. Your company offers competitors of other } \\
\text { competitors } \\
\text { 5. The company gives the best service facilities } \\
\text { for consumers }\end{array}$ \\
\hline 3. & $\begin{array}{c}\text { Enterprise Risk } \\
\text { Management }\end{array}$ & $\begin{array}{l}\text { can be specific risks (eg credit, } \\
\text { operations, and markets), } \\
\text { capital management, and } \\
\text { interpret Enterprise risk } \\
\text { management (ERM) is defined } \\
\text { as risk competency within a } \\
\text { company or organization }\end{array}$ & $\begin{array}{l}\text { 1. The company does precious risk prevention } \\
\text { 2. Your company do true identification of risk } \\
\text { 3. Your company keep the quality of product well } \\
\text { 4. Your company keeps to risk not arising } \\
\text { 5. Your company does risk prevention strategies }\end{array}$ \\
\hline 4 & Risk Mitigaton & $\begin{array}{l}\text { Definition of mitigation is a } \\
\text { series of efforts to reduce } \\
\text { disaster risk, both through } \\
\text { physical development and } \\
\text { awareness and capacity } \\
\text { building in the face of disaster } \\
\text { threats. }\end{array}$ & $\begin{array}{l}\text { 1. Company have a standard procedure for } \\
\text { identification of risk in companies } \\
\text { 2. The company can set up and manage risk in the } \\
\text { company } \\
\text { 3. The company can minimize the risk that will } \\
\text { happen to the company } \\
\text { 4. The company minimizes the risk that will } \\
\text { appear } \\
\text { 5. Your company does evaluate product risk tn } \\
\text { the company }\end{array}$ \\
\hline
\end{tabular}

\section{Result and Discussion}

5.1 Demographic Data

Before discussing the results of 52 respondents to the questionnaire that the researcher spread, first the researcher 
will discuss the general description of the respondents themselves. The general description of the respondents shows everything that is closely related to the respondents themselves individually.

The characteristics of the research respondents were profiles of 52 respondents who participated in filling out the research questionnaire. Profile of respondents explained about gender, age, length of work, education level, and occupation.

Table 5.1

Demographic Data

\begin{tabular}{|c|c|c|}
\hline \multicolumn{3}{|c|}{ Gender } \\
\hline & Frequency & Percent \\
\hline Valid & 1 & 1.9 \\
\hline Man & 28 & 53.8 \\
\hline Woman & 23 & 44.2 \\
\hline Total & 52 & 100 \\
\hline \multicolumn{3}{|c|}{ Education } \\
\hline & Frequency & Percent \\
\hline Senior High School & 37 & 28.8 \\
\hline Bachelor & 15 & 72.1 \\
\hline Total & 52 & 100 \\
\hline \multicolumn{3}{|c|}{ Length of Work } \\
\hline & Frequency & Percent \\
\hline$<1$ years & 6 & 11.5 \\
\hline $1-2$ years & 8 & 15.4 \\
\hline $3-4$ Years & 27 & 51.9 \\
\hline$>5$ Years & 10 & 19.2 \\
\hline valid & 1 & 1.9 \\
\hline Total & 52 & 100 \\
\hline \multicolumn{3}{|c|}{ Age } \\
\hline & Frequency & Percent \\
\hline $18-21$ & 9 & 17.3 \\
\hline $22-24$ & 11 & 21.2 \\
\hline $25-27$ & 26 & 50.0 \\
\hline$>30$ & 6 & 11.5 \\
\hline Total & 52 & 100 \\
\hline
\end{tabular}


Table 5.2

Validity and Reability Test

\begin{tabular}{|c|c|c|}
\hline Perishable Food Supply Chain & Validity $(>0.3)$ & Realibility \\
\hline Q1 & 0,724 & \multirow{5}{*}{0.739} \\
\hline Q2 & 0,502 & \\
\hline Q3 & 0,617 & \\
\hline Q4 & 0,492 & \\
\hline Q5 & 0,715 & \\
\hline Supply Chain Management & Validity $(>0.3)$ & Realibility \\
\hline Q6 & 0,641 & \multirow{5}{*}{0.674} \\
\hline Q7 & 0,397 & \\
\hline Q8 & 0,611 & \\
\hline Q9 & 0,420 & \\
\hline Q10 & 0,522 & \\
\hline Risk Mitigation & Validity $(>0.3)$ & Realibility \\
\hline Q11 & 0,701 & \multirow{5}{*}{0.708} \\
\hline Q12 & 0,485 & \\
\hline Q13 & 0,540 & \\
\hline Q14 & 0,487 & \\
\hline Q15 & 0,583 & \\
\hline Enterprise Risk Management & Validity $(>0.3)$ & Realibility \\
\hline Q16 & 0,776 & \multirow{5}{*}{0.768} \\
\hline Q17 & 0,528 & \\
\hline Q18 & 0,799 & \\
\hline Q19 & 0,519 & \\
\hline Q20 & 0,748 & \\
\hline
\end{tabular}

\subsection{Path Analysis}

In this study the method used is Path Analysis. Path analysis is a development technique from multiple linear regression. This technique is used to test the amount of contribution (contribution) shown by the path coefficient on each path diagram of the causal relationship between variables X1 X2 and X3 to Y and its impact on Z. Path analysis using SPSS version 22 software uses 2 path analysis. The first path analysis is: 
Table 5.3

First Path Analysis

COEFFICIENT

\begin{tabular}{|c|c|c|c|c|c|}
\hline \multirow{2}{*}{ Model } & \multicolumn{2}{|c|}{ Unstandardized Coefficients } & standardized Coefficients & $\mathrm{t}$ & Sig. \\
\cline { 2 - 6 } & $\mathrm{B}$ & Std Error & Beta & & \\
\hline 1 (Constant) & 10.343 & 3.374 & & 3.066 & .004 \\
\hline Perishable Food Supply Chain & .439 & .184 & .401 & 2.386 & .021 \\
\hline Supply Chain Management & -0.38 & .243 & -0.26 & -.155 & .877 \\
\hline
\end{tabular}

a. Dependent Variable : ENTERPRISE RISK MANAGEMENT

ANOVA

\begin{tabular}{|c|l|l|l|l|l|}
\hline Model & Sum of Squares & Df & Mean Square & F & Sig \\
\hline 1. Regression & 35.621 & 2 & 17.810 & 4.269 & .020 \\
\hline Residual & 204.437 & 49 & 4.172 & & \\
\hline Total & 240.058 & 51 & & & \\
\hline
\end{tabular}

a. Dependent Variable : Enterprise Risk Management

b. Predictors : (Constant), SUPPLY CHAIN MANAGEMENT, PERISHABLE FOOD SUPPLY CHAIN

Variables Entered/Removed

\begin{tabular}{|c|c|c|c|}
\hline Model & Variables Entered & Variables Removed & Method \\
\hline 1 & $\begin{array}{c}\text { Supply Chain Management } \\
\text { Perishable Food Supply Chain }\end{array}$ & & ENTER \\
\hline
\end{tabular}

a. Dependent Variable : Enterprise Risk Management

b. All requested variables entered

Model Summary

\begin{tabular}{|l|l|l|l|l|}
\hline Model & R & R Square & Adjusted R Square & Std.Eror Of The Estimate \\
\hline 1 & .385 & .148 & .114 & 2.04259 \\
\hline
\end{tabular}

a. Predictors : (Constant), SUPPLY CHAIN MANAGEMENT, PERISHABLE FOOD SUPPLY CHAIN

Table 5.4

Second Path Analysis

COEFFICIENT

\begin{tabular}{|c|c|c|c|c|c|}
\hline \multirow{2}{*}{ Model } & \multicolumn{2}{|c|}{ Unstandardized Coefficients } & standardized Coefficients & $\mathrm{t}$ & Sig. \\
\cline { 2 - 6 } & $\mathrm{B}$ & Std Error & Beta & & \\
\hline 1 (Constant) & 3.381 & 2.215 & & 1.527 & .133 \\
\hline Perishable Food Supply Chain & .169 & .117 & .203 & 1.447 & .154 \\
\hline Supply Chain Management & .380 & .146 & .345 & 2.598 & .012 \\
\hline Enterprise Risk Management & .266 & .086 & .350 & 3.093 & .003 \\
\hline
\end{tabular}

a. Dependent Variable : RISK MITIGATION

\begin{tabular}{|c|c|c|c|c|c|}
\hline Model & Sum of Squares & Df & Mean Square & $\mathrm{F}$ & Sig \\
\hline 1. Regression & 66.281 & 3 & 22.094 & 14.645 & .000 \\
\hline Residual & 72.411 & 48 & 1.509 & & \\
\hline Total & 138.692 & 51 & & & \\
\hline
\end{tabular}

a. Dependent Variable : Risk Mitigation

b. Predictors : (Constant), ENTERPRISE RISK MANAGEMENT, SUPPLY CHAIN MANAGEMENT, PERISHABLE FOOD SUPPLY CHAIN

VARIABLES ENTERED / REMOVED

\begin{tabular}{|l|l|l|l|}
\hline Model & Variables Entered & Variables Removed & Method \\
\hline 1 & $\begin{array}{l}\text { Enterprise Risk Management, Supply } \\
\text { Chain Management, Perishable Food } \\
\text { Supply Chain }\end{array}$ & & \multirow{2}{*}{ Enter } \\
\hline
\end{tabular}

a. Dependent Variable : RISK MITIGATION

\section{MODEL SUMMARY}

\begin{tabular}{|l|l|l|l|l|}
\hline Model & R & R Square & Adjusted R Square & Std. Error of the Estimate \\
\hline 1 & .691 & .478 & .445 & 1.22824 \\
\hline
\end{tabular}

a. Predictors : (Constant),ENTERPRISE RISK MANAGEMENT, SUPPLY CHAIN MANAGEMENT, PERISHABLE FOOD SUPPLY CHAIN 


\section{Conclusion}

6.1 Summary

This study aims to examine the effect of psychological safety and leadership style on risk performance with enterprise risk management as an intervening variable. The sample in this study are employees who work in service companies. The sampling process in this study used a purposive sampling technique and used 52 respondents.

1. Analysis of the effect of X1 on Z

The sig value $\mathrm{X} 1=0.021<0.05$ so that it can be concluded that there is a direct significant effect of Perishable Food Supply Chain on ERM.

2. Analysis of the effect of $\mathrm{X} 2$ on $\mathrm{Z}$

The sig value X2 $=0.877>0.05$ so that it can be concluded that Supply Chain Management directly does not have a significant effect on ERM

3. Analysis of the influence of $\mathrm{Z}$ on $\mathrm{Y}$

The value of $\operatorname{sig} Z=0.003<0.05$ so that it can be concluded that ERM directly has a significant effect on Risk Mitigation

4. Analysis of the effect of X1 on Y

Sig value $\mathrm{X} 1=0.154>0.05$ So that it can be concluded that Perishable Food Supply Chain does not have a significant effect on Risk Mitigation

5. Analysis of the Effect of X2 on Y

Sig value X2 $=0.012<0.05$ So that it can be concluded that Perishable Food Supply Chain has a significant effect on Risk Mitigation

6. Effect Analysis of X1 through Z on Y

Direct influence given $\mathrm{X} 1$ to $\mathrm{Y}$ is 0.169 , while the indirect effect of $\mathrm{X} 1$ through $\mathrm{Z}$ to $\mathrm{Y}$ is multiplication between the value of beta $\mathrm{X} 1$ to $\mathrm{Z}$ with beta value $\mathrm{Z}$ to $\mathrm{Y}$ which is $0.439 \times 0.266=0.116$.

Then the total influence given $\mathrm{X} 1$ to $\mathrm{Y}$ is a direct effect coupled with an indirect influence namely $0.169+0.116$ $=0.285$

Indirect influence $<$ direct effect, shows that indirectly $\mathrm{x} 1$ through $\mathrm{Z}$ has no significant influence on $\mathrm{Y}$

7. Analysis of the Effect of X2 through $\mathrm{Z}$ on $\mathrm{Y}$

Direct influence given $\mathrm{X} 2$ to $\mathrm{Y}$ is 0.380 , while the indirect effect of $\mathrm{X} 2$ through $\mathrm{Z}$ to $\mathrm{Y}$ is multiplication between the value of beta $X 2$ to $Z$ with beta value $Z$ to $Y$, namely $-0.038 \times 0.266=-0.044$.

Then the total influence given $\mathrm{X} 2$ to $\mathrm{Y}$ is the direct effect coupled with the indirect effect that is $0.380-0.044=-$ 0.336

Indirect influence < direct effect, shows that indirectly $\mathrm{x} 2$ through $\mathrm{Z}$ does not have a significant effect on $\mathrm{Y}$

\subsection{Limitation}

1. This study only uses a sample of companies engaged in retail companies in the consumer goods industry sector so that the results of the study cannot be generalized.

2. This study only uses 52 respondents, it is felt that the number is still small and has not provided a maximum picture

\subsection{Suggestion}

Suggestion for the next researcher based on the conclusions from the results of the study as described above, the suggestions that can be given are as follows:

1. In this study using more retail companies, the next researcher should be able to add years of research, resulting in more varied and better research results.

2. In further research, it is expected to add other variables so that they will be more varied. 